\title{
Effects of Lanthanum on the Photosystem II Energy Fluxes and Antioxidant System of Chlorella Vulgaris and Phaeodactylum Tricornutum
}

\author{
Dong Sun ${ }^{1}$, Ning $\mathrm{He}^{2}{ }^{\mathbb{D}}$, Qi Chen ${ }^{1}$ and Shunshan Duan ${ }^{1, *}$ \\ 1 Research Center of Hydrobiology, Key Laboratory of Aquatic Eutrophication and Control of Harmful Algal \\ Blooms of Guangdong Higher Education Institute, Jinan University, Guangzhou 510632, China; \\ jnu_sundong@163.com (D.S.); cq92088@outlook.com (Q.C.) \\ 2 Colleges of Life Science and Resource and Environment, Yichun University, Yichun 336000, China; \\ hening2010@163.com \\ * Correspondence: tssduan@jnu.edu.cn or dsun@jnu.edu.cn
}

Received: 13 May 2019; Accepted: 19 June 2019; Published: 25 June 2019

\begin{abstract}
The rare earth elements are widely used in agricultural and light industry development. They promote the growth of crop seedlings, enhance root development and change the metal properties. Due to the large amount of rare earth minerals mined in China, rare earth elements have been detected in both coastal and estuary areas. They cause pollution and threaten the health of aquatic organisms and human beings. This study investigates the effects of lanthanum on two marine bait algae, and analyzes the changes in the photosynthetic and antioxidant systems of the two algae. The results show that rare earth elements have significant inhibitory effects upon the two algae. The OJIP kinetic curve value decreases with an increasing concentration of $\mathrm{La}\left(\mathrm{NO}_{3}\right)_{3} \cdot 6 \mathrm{H}_{2} \mathrm{O}$. The parameters of the fluorescence value were analyzed. The $\mathrm{ABS} / \mathrm{RC}$ increases and the $\mathrm{DI}_{0} / \mathrm{RC}$ decreases during the first $24 \mathrm{~h}$ after exposure. The effects on the photosynthetic and antioxidant systems at low concentrations (both $\mathrm{EC}_{10}$ and $\mathrm{EC}_{20}$ ) show that the $\mathrm{TR}_{0} / \mathrm{ABS}$ increases, and the $\mathrm{ET}_{0} / \mathrm{RC}$, $\mathrm{ABS} / \mathrm{RC}$, and $\mathrm{DI}_{0} / \mathrm{RC}$ has a decreasing trend after $30 \mathrm{~min}$. However, after $24 \mathrm{~h}$, normal levels were restored. In addition, the study finds that the $\mathrm{TR}_{0} / \mathrm{ABS}$ increases after $24 \mathrm{~h}$, leading to an increase in reactive oxygen species. The antioxidant system analysis also confirms the increase in the activities of antioxidant enzymes, such as SOD and GSH. The experiment is expected to support the marine pollution of rare earths and the theoretical data of the impact on marine primary producers.
\end{abstract}

Keywords: Antioxidant system; bait algae; photosystem II; pollution; rare earth elements

\section{Introduction}

The rare earth elements (REEs) are a series of metal elements with similar physical and chemical properties. China holds a near monopoly on the production of REEs in many years, and contains the largest mineral deposits in the world [1,2]. In the last several decades, the exploitation and use of rare earth sources improves economic and agricultural development. REEs have received increasing attention in recent years because they contaminate the environment and cause potential harm to organisms [3-5]. Some studies report that REEs are largely found in the air [6], soil [7], sediments [8], and water [9]. Moreover, they are also detected in vegetables [10], fishes [11], and especially in human urine and hair $[12,13]$. Some REEs cause damage to organisms and also cause human diseases. Other studies reported that REEs accumulate in organisms [14] and are toxic at environmental concentrations. Hence, the adverse effects of REEs on aquatic organisms need further exploration.

Algae are an important part of oceans and the primary producer in the marine ecosystem. Hence, the growth of algae is often used to assess the pollution conditions in the water environment. REEs 
inevitably affect the algae in the water. Some reports showed that a high concentration of REEs inhibits the growth of plants and algae $[15,16]$. A few studies have been conducted on the toxic effects of REEs on algae. However, whether photosystem (PS) II was damaged or the antioxidant system was disordered is still unclear $[17,18]$. Therefore, the inhibitory effects of REE exposure need to be investigated further.

The photosynthetic processes support the biochemical reactions needed for the growth of algae. Thus, changes in external environmental conditions disrupt the balance for PS and the ability to use light energy [19]. Some reports show that the heavy metals damage plant chloroplast or photosynthetic organs and reduce photosynthetic efficiency [20]. The OJIP test is used to assess the response of plants and algae to environmental stresses and the effect on PS II [21,22]. However, a few studies are performed on the effects of REEs on the algal chlorophyll $a$ fluorescence, especially the photochemical reaction. When the algal cells are subjected to pollution stress, the oxygen in the cells is converted into the damaging reactive oxygen species (ROS). The ROS and their products have a strong oxidizing ability and destroy many biomolecules [23,24]. The superoxide dismutase (SOD), glutathione (GSH), peroxidase (POD), and catalase (CAT) belong to the antioxidant enzyme system and indicate the extent of algal cell damage [25]. Therefore, many studies have used these indicators to reflect the algae conditions [26-28].

The investigations on the toxic effects of rare earth pollutants on the photosynthetic and antioxidant responses of algae are limited. Thus, this study aimed to: (1) Investigate the toxic effect of $\mathrm{La}\left(\mathrm{NO}_{3}\right)_{3} \cdot 6 \mathrm{H}_{2} \mathrm{O}$ on Chlorella vulgaris and Phaeodactylum tricornutum, including the growth, photosynthetic, and antioxidant responses; and (2) to analyze whether the inhibition effect was due to the destruction of the photosynthetic system or of the oxidation system.

\section{Materials and Methods}

\subsection{Algae Culture}

Marine microalgae $C$. vulgaris and P. tricornutum were obtained from the Research Center of Hydrobiology, Jinan University, Guangzhou, China. These two marine microalgae cultures were obtained using artificial seawater enriched with a modification of $f / 2$ medium without ethylenediaminetetraacetic acid (EDTA), (the initial $\mathrm{pH}$ was adjusted to 8.0 with $0.5 \mathrm{~mol} \cdot \mathrm{L}^{-1} \mathrm{HCl}$ or $\mathrm{NaOH}$ ). EDTA greatly decreases the toxicity of elements due to the chelating properties of the molecules [29]. The $\mathrm{f} / 2$ media contained all of the essential elements and trace elements necessary for the algae growth. Culture of $C$. vulgaris and P. tricornutum was carried out in 2-L flasks, with each flask containing $1 \mathrm{~L}$ of the medium. The culture was illuminated with fluorescent light at a light intensity of $35 \mu \mathrm{mol} \cdot \mathrm{s}^{-1} \cdot \mathrm{m}^{-2}$ at the surface of the culture medium, while with a 12/12-h light/dark cycle in an environmental chamber at $23{ }^{\circ} \mathrm{C} \pm 1{ }^{\circ} \mathrm{C}$. This culture period had $3-5$ cycles (7-9 days per cycle) to activate the microalgae to follow on the experiment.

\subsection{Experimental Design}

C. vulgaris and $P$. tricornutum were grown in the $\mathrm{f} / 2$ medium with $\mathrm{La}\left(\mathrm{NO}_{3}\right)_{3} \cdot 6 \mathrm{H}_{2} \mathrm{O}$. The effects of $\mathrm{La}\left(\mathrm{NO}_{3}\right)_{3} \cdot 6 \mathrm{H}_{2} \mathrm{O}$ at concentrations of $0,2,4,6,8$, and $10 \mathrm{mg} \cdot \mathrm{L}^{-1}$ on microalgae growth were assessed and fluorescence transient measurements were conducted. Cultivations were performed in $150-\mathrm{mL}$ flasks $\left(100-\mathrm{mL}\right.$ culture medium) in triplicate at $23^{\circ} \mathrm{C} \pm 1{ }^{\circ} \mathrm{C}$ and $35 \mu \mathrm{mol} \cdot \mathrm{s}^{-1} \cdot \mathrm{m}^{-2}$ under a $12 / 12-\mathrm{h}$ light/dark cycle. The inoculation density was $2 \times 10^{5} \mathrm{cell} \cdot \mathrm{mL}^{-1}$. The flasks were shaken by hand and their places were randomly changed three times a day. The algae cell density was determined with a hemocytometer (Qiujing Company, Shanghai, China) three times for each sample under a 400x magnification of the microscope (BX53, OLYMPUS, Japan).

C. vulgaris and P. tricornutum were exposed to $\mathrm{La}\left(\mathrm{NO}_{3}\right)_{3} \cdot 6 \mathrm{H}_{2} \mathrm{O}$ for $96 \mathrm{~h}$. During this period, the growth and fluorescence transient measurements of the two algae were determined daily and used 
to investigate the inhibitory effect of $\mathrm{La}\left(\mathrm{NO}_{3}\right)_{3} \cdot 6 \mathrm{H}_{2} \mathrm{O}$ on algae. After $96 \mathrm{~h}$, the $\mathrm{EC} 10$ and EC20 of $\mathrm{C}$. vulgaris and P. tricornutum were calculated according to the dose-effect formula.

The extent of damage caused by EC10 and EC20 of $\mathrm{La}\left(\mathrm{NO}_{3}\right)_{3} \cdot 6 \mathrm{H}_{2} \mathrm{O}$ to the photosynthetic system II and the antioxidant system of the two algae was observed. Meanwhile, the emergency response and strategy of algae against metal pollutants were examined.

\subsection{Measurements of Fluorescence Transient}

The fluorescence transient was measured using a Handy Plant Efficiency Analyzer (Hansatech Ltd., UK). Measurements were performed on 2-mL samples in 6-mm-diameter transparent vials, which were dark-adapted for $15 \mathrm{~min}$ at room temperature. The fluorescence transients were recorded for up to $2 \mathrm{~s}$ in a logarithmic time scale. The selected OJIP test parameters (Table 1 ) to quantify the fluorescence were calculated from the original data using the formula described by previous research $[21,22,30]$.

The following equations were used to evaluate the energy fluxes in PS II:

The trapping probability or the maximum efficiency of PS II photochemistry, $\mathrm{TR} 0 / \mathrm{ABS}$, or $F_{\mathrm{v}} / F_{\mathrm{m}}=$ $\left(F_{\mathrm{m}}-F_{50 \mu \mathrm{s}}\right) / F_{\mathrm{m}}$

The effective antenna size of an active $\mathrm{RC}$ or absorption flux per $\mathrm{RC}, \mathrm{ABS} / \mathrm{RC}=\left(M_{0} / V_{\mathrm{j}}\right) /\left(\mathrm{TR} \mathrm{R}_{0} / \mathrm{ABS}\right)$, where $V_{\mathrm{j}}=\left(F_{2 \mathrm{~ms}}-F_{50 \mu \mathrm{s}}\right) /\left(F_{\mathrm{m}}-F_{50 \mu \mathrm{s}}\right)$

The effective dissipation of an active $\mathrm{RC}, \mathrm{DI}_{0} / \mathrm{RC}=(\mathrm{ABS} / \mathrm{RC})-\left(M_{0} / V_{\mathrm{j}}\right)$

The electron transport rate in an active $\mathrm{RC}, \mathrm{ET}_{0} / \mathrm{RC}=\left(M_{0} / V_{\mathrm{j}}\right) \times\left(1-V_{\mathrm{j}}\right)$

Table 1. Parameters used in the analysis of OJIP fluorescence induction dynamics curves $[21,22,30]$.

\begin{tabular}{ll}
\hline \multicolumn{1}{c}{ Terms } & \multicolumn{1}{c}{ Illustration } \\
\hline$F_{0}$ & Minimal recorded fluorescence intensity \\
$F_{m}$ & Maximal recorded fluorescence intensity \\
$F_{50 \mu \mathrm{s},} F_{2} \mathrm{~ms}$ & Fluorescence intensities at $50 \mu \mathrm{s}$ and $2 \mathrm{~ms}$ \\
$\mathrm{OJIP}$ & O phase $\left(F_{20 \mu s} / F_{0}\right), \mathrm{J}$ phase $\left(F_{2 \mathrm{~ms}}\right), \mathrm{I}$ phase $\left(F_{30 \mathrm{~ms}}\right)$ and P phase $\left(F_{m}\right)$ \\
$V_{j}$ & Relative variable fluorescence intensity at the J-step \\
$M_{0}$ & Approximated initial slope of the fluorescence transient \\
$\mathrm{RC}$ & Reaction center of photosystem II \\
\hline
\end{tabular}

\subsection{Extraction and Determination of Protein and Antioxidase Levels}

After exposure to $\mathrm{EC}_{10}$ and $\mathrm{EC}_{20}$ for $96 \mathrm{~h}$, the flasks with microalgae were taken out and shaken by hand. Then, $40 \mathrm{~mL}$ of microalgae cells in each flask were sampled after $1 \mathrm{~h}$ (the dead cells precipitated to the bottom) and centrifuged at $7500 \mathrm{rpm}$ for $10 \mathrm{~min}$ at $4{ }^{\circ} \mathrm{C}$. The liquid supernatant was discarded, followed by ultrasonic (UH-950B, Tianjing, China) disruption (5-s ultrasound and 5-s stop) after adding $9 \mathrm{~mL}$ of saline for $30 \mathrm{~min}$ in the ice-water bath. These samples were centrifuged at $7500 \mathrm{rpm}$ for $10 \mathrm{~min}$ at $4{ }^{\circ} \mathrm{C}$, and the liquid supernatant was preserved in vials in the ice-water bath for further experiments.

The total protein concentration was determined with an assay kit purchased from the Nanjing Jiancheng Bioengineering Institute according to bicinchoninic acid assay [31].

The peroxidase (POD) activity was determined with an assay kit purchased from Nanjing Jiancheng Bioengineering Institute following the methods described by Montavon and Bortlik [32]. The reaction was initiated by adding the extract, and the absorbance was read at the $420 \mathrm{~nm}$ wavelength using a UV-visible spectrophotometer (UV-2450, Shimadzu, Japan) for $30 \mathrm{~min}$ at $37^{\circ} \mathrm{C}$. One unit of POD activity was defined as $1 \mu \mathrm{g} \mathrm{H}_{2} \mathrm{O}_{2} \cdot \mathrm{mg}^{-1}$ protein $\cdot \mathrm{min}^{-1}$.

The activity of superoxide dismutase (SOD) was determined using an assay kit of WST-1 purchased from Nanjing Jiancheng Bioengineering Institute. Water-soluble tetrazolium was used as the detector of the superoxide radicals generated by xanthine oxidase and hypoxanthine in the presence of a range of concentrations of SOD [33]. One unit of SOD activity was defined as the amount of enzyme inhibiting $50 \%$ of WST-1 photoreduction [34]. 
The catalase (CAT) activity was determined using an assay kit purchased from the Nanjing Jiancheng Bioengineering Institute. The absorbance at $405 \mathrm{~nm}$ of the reaction liquid was measured with a UV-visible spectrophotometer as described by Góth [35]. One unit of CAT activity was defined as $1 \mu \mathrm{mol} \mathrm{H}_{2} \mathrm{O}_{2} \cdot \mathrm{mg}^{-1}$ protein $\cdot \mathrm{s}^{-1}$.

The glutathione (GSH) concentration was determined with an assay kit purchased from the same Nanjing Jiancheng Bioengineering Institute based on the reaction of 5.5'-dithio-bis (2-nitrobenzoic acid) with sulfhydryl compound as described by Anderson [36]. The content of GSH was calculated based on the standard curve.

\subsection{Data Analysis and Statistics}

Data were expressed as means and standard deviations replicated three times. Origin 8.0 (Origin Lab, Northampton, MA) was used to construct the figures. The data were analyzed using the one-way analysis of variance (ANOVA). If the statistical test was significant at $p<0.05$, the differences were compared using the LSD comparison method with the SPSS 17.0 for Windows (SPSS, Chicago, IL, USA).

\section{Results}

\subsection{The Toxicity Effect of $\mathrm{La}\left(\mathrm{NO}_{3}\right)_{3} \cdot 6 \mathrm{H}_{2} \mathrm{O}$ on the Two Algae}

Five different concentrations of $\mathrm{La}\left(\mathrm{NO}_{3}\right)_{3} \cdot 6 \mathrm{H}_{2} \mathrm{O}$ are used to inhibit the growth of the two marine microalgae for $96 \mathrm{~h}$ (Figure 1). The results show that $\mathrm{La}\left(\mathrm{NO}_{3}\right)_{3} \cdot 6 \mathrm{H}_{2} \mathrm{O}$ has inhibitory effects on both marine microalgae. When the concentrations of $\mathrm{La}\left(\mathrm{NO}_{3}\right)_{3} \cdot 6 \mathrm{H}_{2} \mathrm{O}$ increase, the inhibition rates increase. According to the dose-effect formula, the $\mathrm{EC}_{50}$ value of $C$. vulgaris and P. tricornutum is $10.077 \mathrm{mg} \cdot \mathrm{L}^{-1}$ and $5.665 \mathrm{mg} \cdot \mathrm{L}^{-1}$, respectively. After $96 \mathrm{~h}, 10 \mathrm{mg} \cdot \mathrm{L}^{-1} \mathrm{La}\left(\mathrm{NO}_{3}\right)_{3} \cdot 6 \mathrm{H}_{2} \mathrm{O}$ could inhibit $96 \%$ of $P$. tricornutum. Thus, $\mathrm{La}\left(\mathrm{NO}_{3}\right)_{3} \cdot 6 \mathrm{H}_{2} \mathrm{O}$ has a strong toxic effect on the two microalgae.

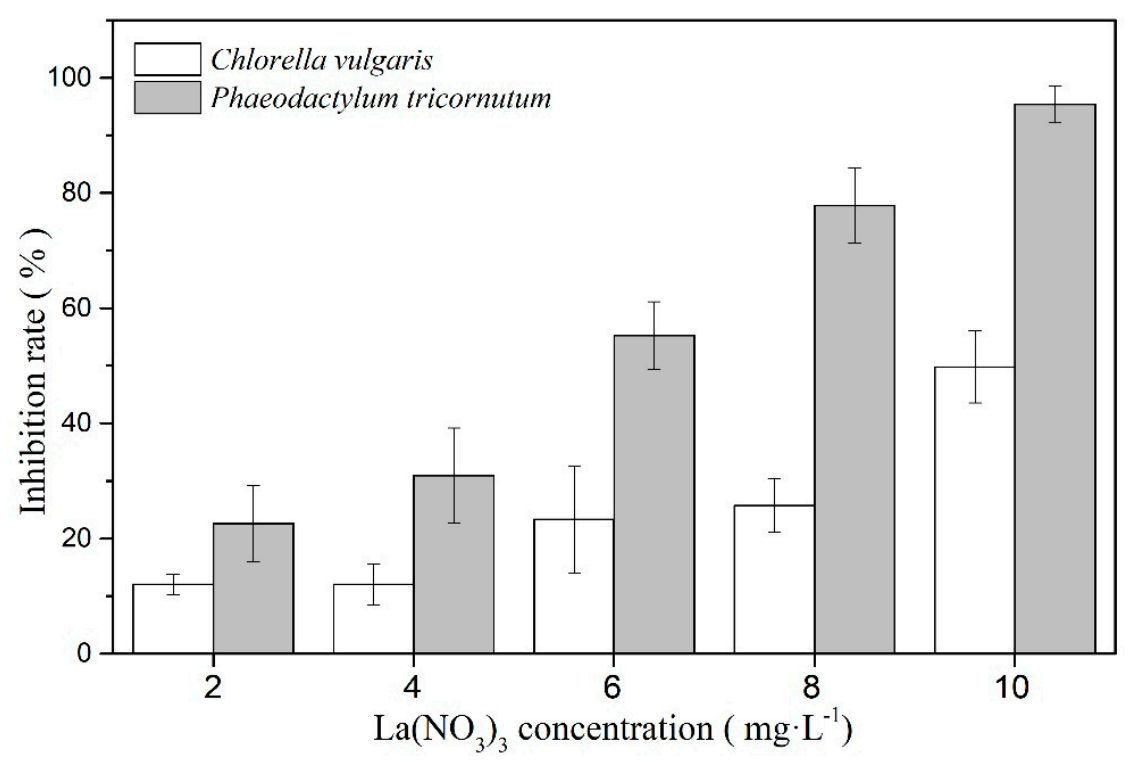

Figure 1. Inhibition rate for various concentrations of $\mathrm{La}\left(\mathrm{NO}_{3}\right)_{3} \cdot 6 \mathrm{H}_{2} \mathrm{O}$ in $96 \mathrm{~h}$.

\subsection{Effect of $\mathrm{La}\left(\mathrm{NO}_{3}\right)_{3} \cdot 6 \mathrm{H}_{2} \mathrm{O}$ on PS II of the Two Microalgae}

Figure 2 (OJIP curves) shows the chlorophyll fluorescence transients of $C$. vulgaris and P. tricornutum exposed to different concentrations of $\mathrm{La}\left(\mathrm{NO}_{3}\right)_{3} \cdot 6 \mathrm{H}_{2} \mathrm{O}$ for $96 \mathrm{~h}$. When the concentration of $\mathrm{La}\left(\mathrm{NO}_{3}\right)_{3} \cdot 6 \mathrm{H}_{2} \mathrm{O}$ increases, the fluorescence transients of $C$. vulgaris and P. tricornutum significantly decrease, and are lower compared with the control. When the concentration is at $10 \mathrm{mg} \cdot \mathrm{L}^{-1}$, maximum fluorescence is observed ( $F_{\mathrm{m}}$ or P point). However, the fluorescence transients of P. tricornutum decrease 
rapidly compared with those of $C$. vulgaris at the same concentration of $\mathrm{La}\left(\mathrm{NO}_{3}\right)_{3} \cdot 6 \mathrm{H}_{2} \mathrm{O}$. These results indicate that $C$. vulgaris is more resistant than P. tricornutum.

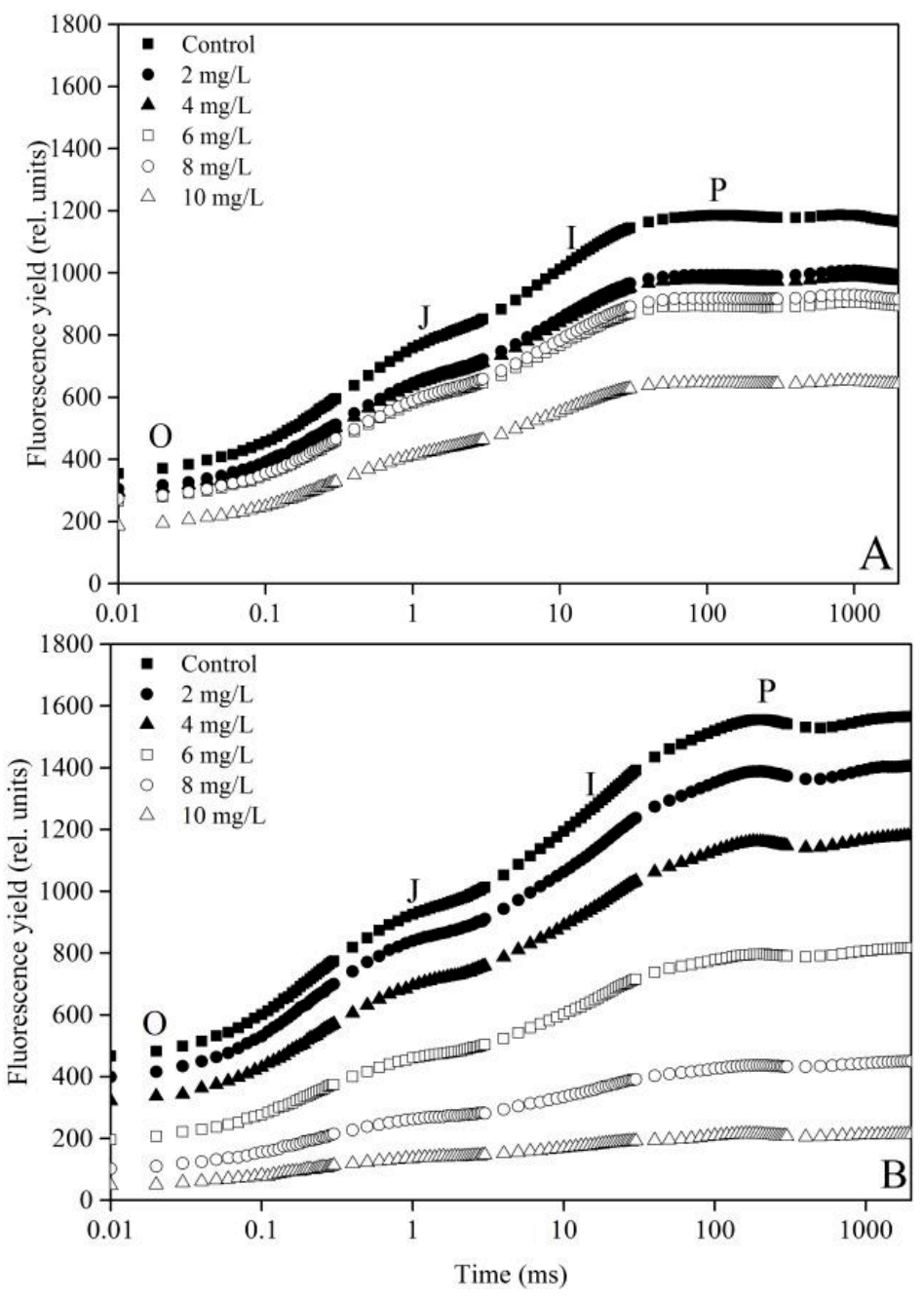

Figure 2. Rapid increase in fluorescence transients for C. vulgaris (A) and P. tricornutum (B) exposed to $\mathrm{La}\left(\mathrm{NO}_{3}\right)_{3} \cdot 6 \mathrm{H}_{2} \mathrm{O}$ for $96 \mathrm{~h}$.

As shown in Figure 3A, ABS/RC has no significant difference between groups. $\mathrm{DI}_{0} / \mathrm{RC}$ decreases significantly with an increasing concentration of $\mathrm{La}\left(\mathrm{NO}_{3}\right)_{3} \cdot 6 \mathrm{H}_{2} \mathrm{O}$ after $24 \mathrm{~h}$ and recovers after $48 \mathrm{~h}$, but the effects at 6 and $10 \mathrm{mg} \cdot \mathrm{L}^{-1}$ are still significantly lower compared with the control. After $72 \mathrm{~h}$, no significant difference is found between the groups. $\mathrm{ET}_{0} / \mathrm{RC}$ is significantly higher in the $10 \mathrm{mg} \mathrm{L}^{-1}$ group compared with the control after $24 \mathrm{~h}$; the value in the $6 \mathrm{mg} \cdot \mathrm{L}^{-1}$ group is lower compared with the control after $48 \mathrm{~h}$. After $72 \mathrm{~h}$, the $\mathrm{ET}_{0} / \mathrm{RC}$ values have no significant difference between groups. $\mathrm{TR}_{0} / \mathrm{ABS}$ increased significantly with increasing concentrations of $\mathrm{La}\left(\mathrm{NO}_{3}\right)_{3} \cdot 6 \mathrm{H}_{2} \mathrm{O}$ after $24 \mathrm{~h}$. After $48 \mathrm{~h}$, no significant difference is found between the groups.

As shown in Figure 3B, ABS/RC is lower compared with the control after $24 \mathrm{~h}$. No significant difference is found between groups after $48 \mathrm{~h} . \mathrm{DI}_{0} / \mathrm{RC}$ is significantly lower compared with the control and decreases with the decreasing concentration of $\mathrm{La}\left(\mathrm{NO}_{3}\right)_{3} \cdot 6 \mathrm{H}_{2} \mathrm{O}$ after $24 \mathrm{~h}$. After $48 \mathrm{~h}$, the $\mathrm{DI}_{0} / \mathrm{RC}$ recovers but is still significantly lower compared with the control. After $72 \mathrm{~h}, \mathrm{DI}_{0} / \mathrm{RC}$ returns to the control levels, but is still not stable. $\mathrm{ET}_{0} / \mathrm{RC}$ significantly decreases at a high concentration $\left(10 \mathrm{mg} \cdot \mathrm{L}^{-1}\right)$ after $24 \mathrm{~h}$ and is significantly lower compared with the control in the $6 \mathrm{mg} \cdot \mathrm{L}^{-1}$ group after $48 \mathrm{~h}$. After $72 \mathrm{~h}$, the groups have no significant difference compared with the control. TR $0 / \mathrm{ABS}$ is significantly 
higher compared with the control before $48 \mathrm{~h}$, and has no significant difference between groups after $72 \mathrm{~h}$.
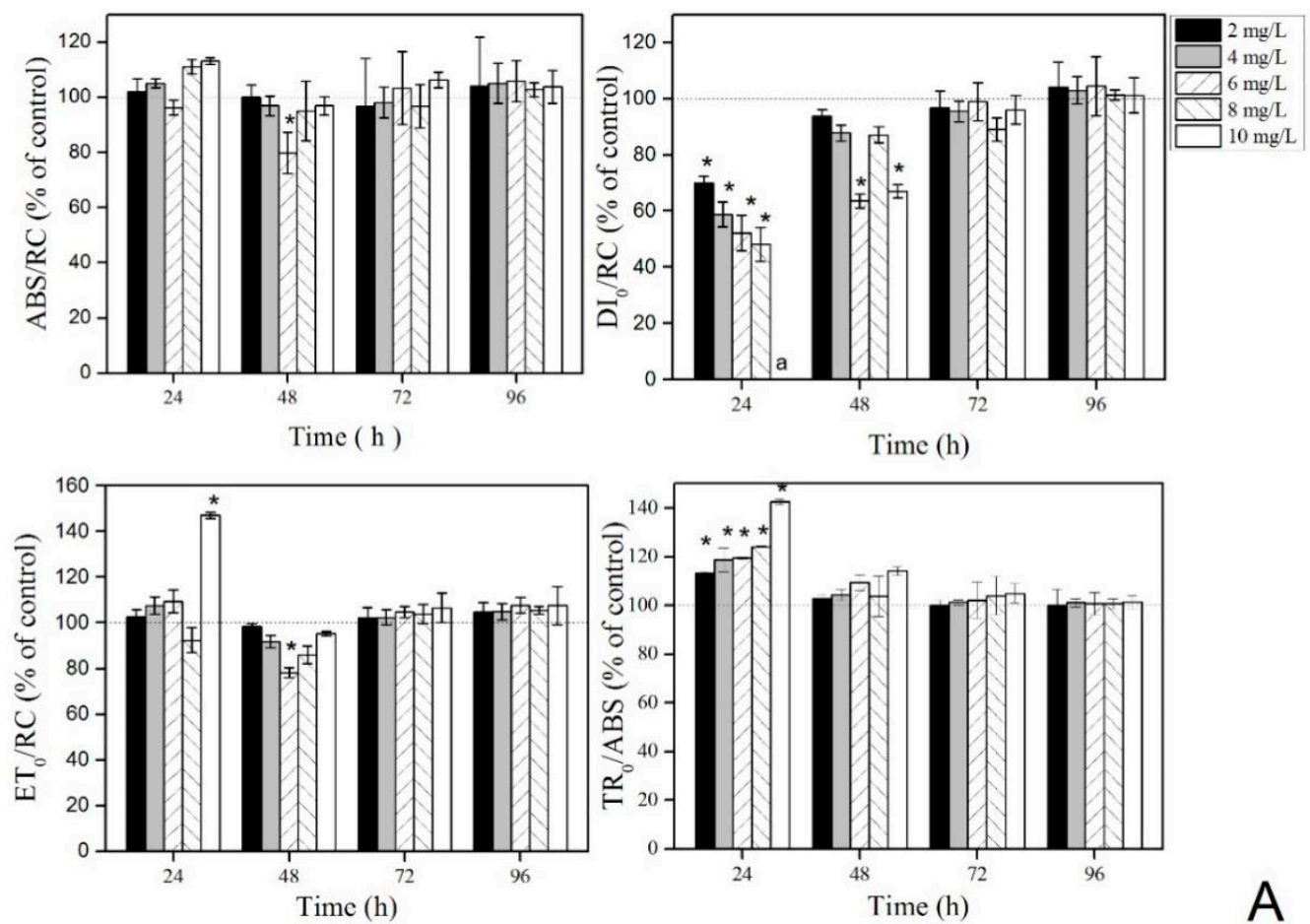

A
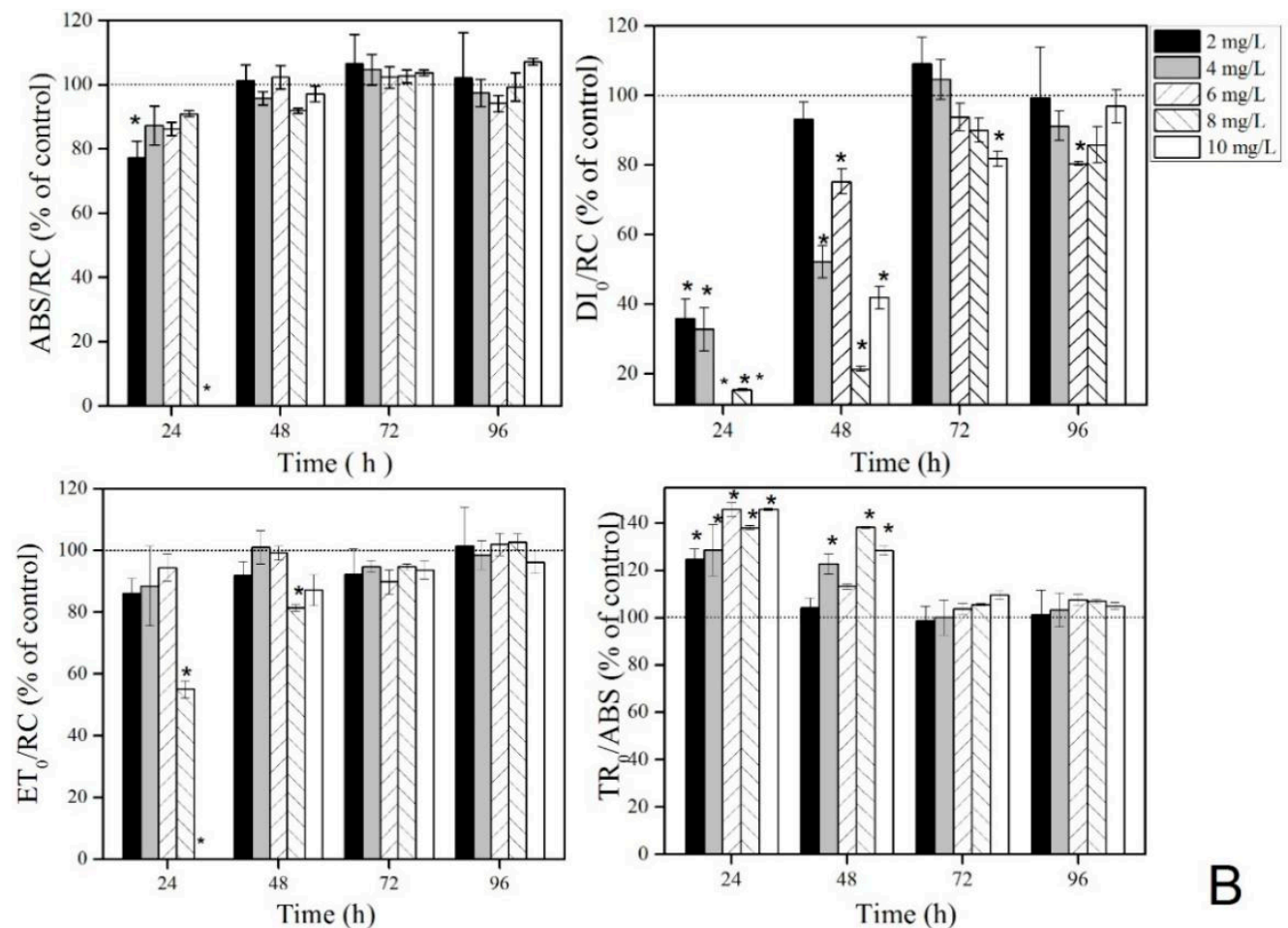

Figure 3. OJIP-test parameters expressed as a percentage of the control when C. vulgaris (A) and $P$. tricornutum (B) were treated with $\mathrm{La}\left(\mathrm{NO}_{3}\right)_{3} \cdot 6 \mathrm{H}_{2} \mathrm{O}$ and dark-adapted for $15 \mathrm{~min}$. * Significant difference compared with the control $(p<0.05)$. ${ }^{\text {a }}$ The value was too low to be measured. 


\subsection{Effect of Low Concentrations ( $E C_{10}$ and $E C_{20}$ ) of La(NO3)3.6 $\mathrm{H}_{2} \mathrm{O}$ on PS II and Antioxidant Enzyme System}

The results indicate that $\mathrm{La}\left(\mathrm{NO}_{3}\right)_{3} \cdot 6 \mathrm{H}_{2} \mathrm{O}$ indeed inhibits the growth of algae, but whether the inhibition of algae growth is due to the destruction of photosynthetic or oxidation-reduction system is not clear. Hence, $\mathrm{EC}_{10}$ and $\mathrm{EC}_{20}$ of $\mathrm{La}\left(\mathrm{NO}_{3}\right)_{3} \cdot 6 \mathrm{H}_{2} \mathrm{O}$ are used as the experimental concentration for the next experiment (Figure 4). According to the dose-effect formula calculation, the $\mathrm{EC}_{10}$ and $\mathrm{EC}_{20}$ of $C$. vulgaris are 3.271 and $6.404 \mathrm{mg} \cdot \mathrm{L}^{-1}$, and the $\mathrm{EC}_{10}$ and $\mathrm{EC}_{20}$ of P. tricornutum are 1.262 and $2.282 \mathrm{mg} \cdot \mathrm{L}^{-1}$, respectively.
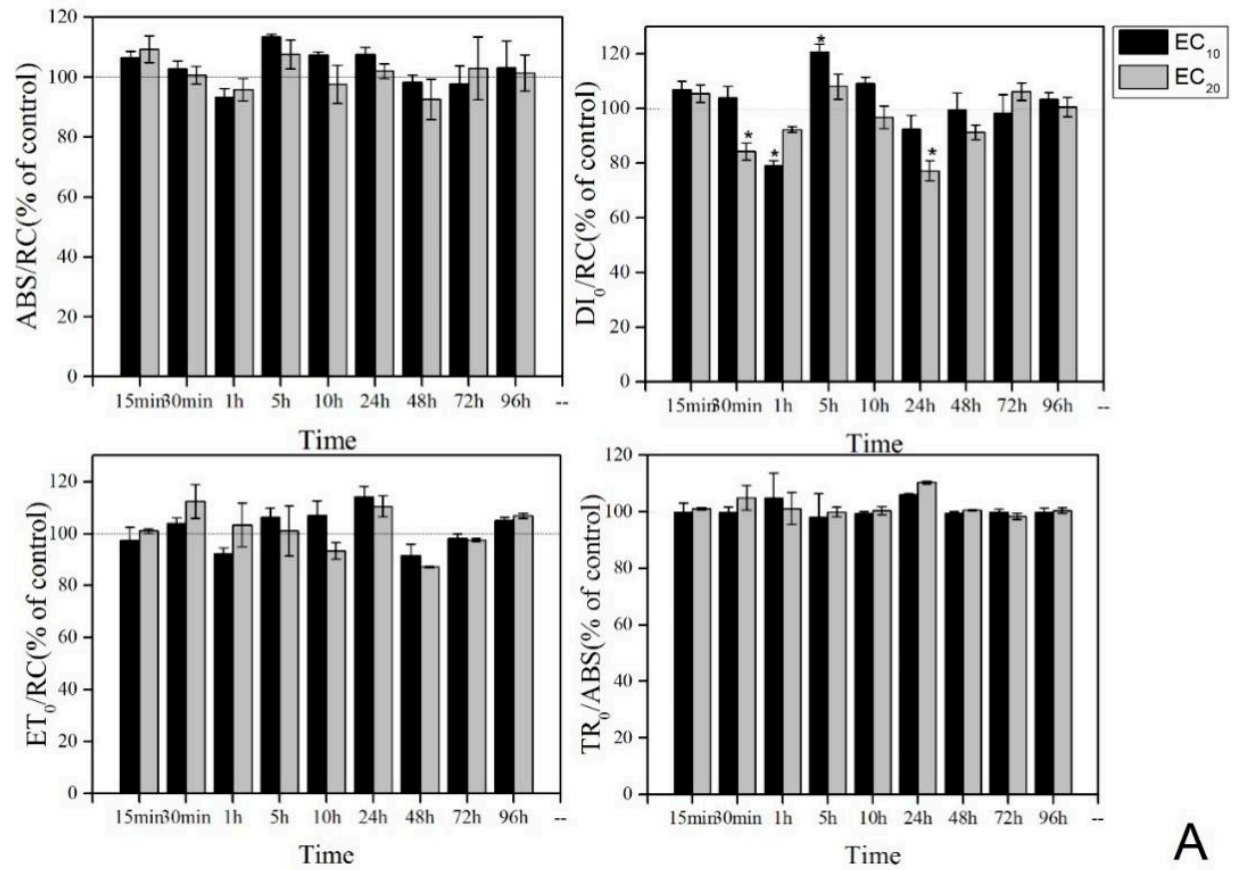

A
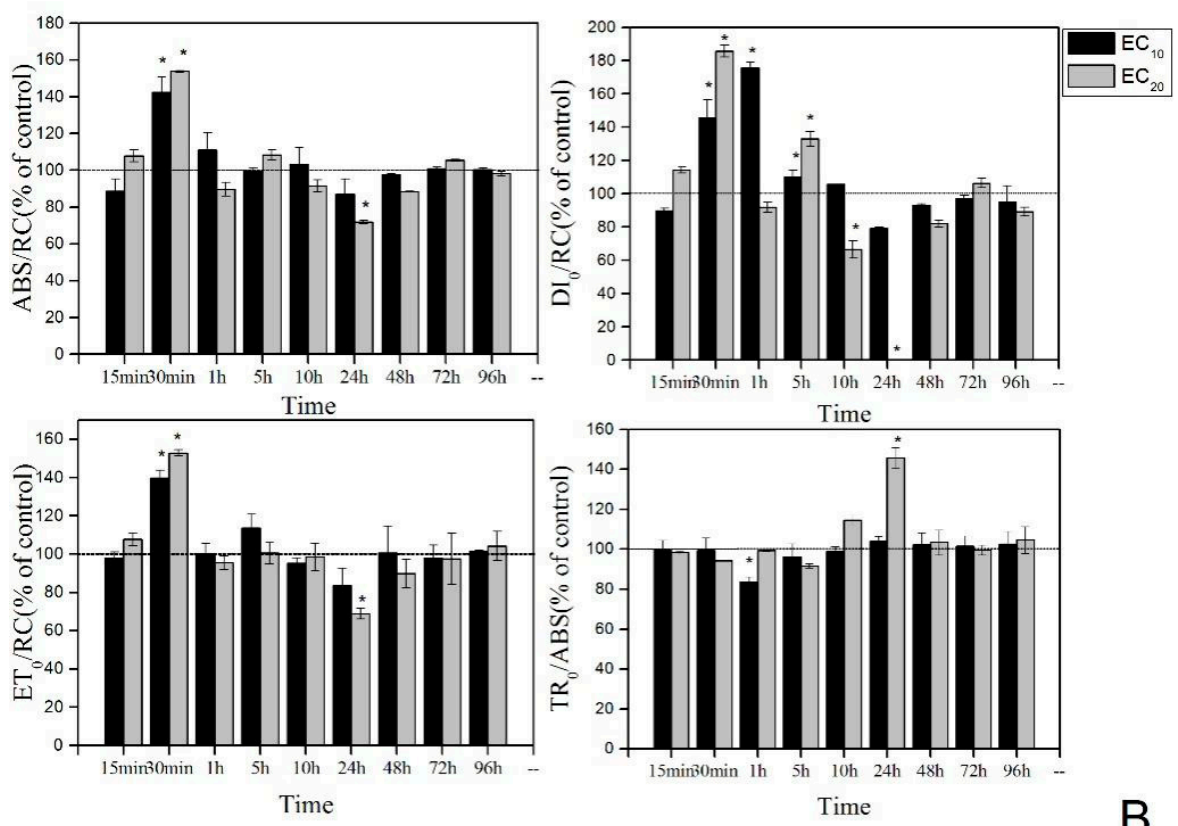

B

Figure 4. OJIP test parameters expressed as a percentage of the control when $C$. vulgaris (A) and $P$. tricornutum (B) were treated with $\mathrm{EC}_{10}$ and $\mathrm{EC}_{20}$ of $\mathrm{La}\left(\mathrm{NO}_{3}\right)_{3} \cdot 6 \mathrm{H}_{2} \mathrm{O}$ and dark-adapted for 15 min. *Significant difference compared with the control $(p<0.05)$. 
After adding $\mathrm{La}\left(\mathrm{NO}_{3}\right)_{3} \cdot 6 \mathrm{H}_{2} \mathrm{O}$, the PS II indicators of $C$. vulgaris have wave-shaped disturbances with time. Although ABS/RC fluctuates, no significant difference is found compared with the control. $\mathrm{DI}_{0} / \mathrm{RC}$ significantly decreases after $30 \mathrm{~min}$ and $24 \mathrm{~h}$, and significantly increases after $5 \mathrm{~h} . \mathrm{ET}_{0} / \mathrm{RC}$ and $\mathrm{TR}_{0} / \mathrm{ABS}$ have no significant difference compared with the control at each time point.

The effect of $\mathrm{La}\left(\mathrm{NO}_{3}\right)_{3} \cdot 6 \mathrm{H}_{2} \mathrm{O}$ is greater on PS II indicators of P. tricornutum than on C. vulgaris. $\mathrm{ABS} / \mathrm{RC}$ significantly increases after $30 \mathrm{~min}$ and then gradually stabilizes to the control. $\mathrm{DI}_{0} / \mathrm{RC}$ significantly increases from $30 \mathrm{~min}$ to $5 \mathrm{~h}$ and decreases after 10 and $24 \mathrm{~h}$. After $48 \mathrm{~h}, \mathrm{DI}_{0} / \mathrm{RC}$ reaches the level of control. $\mathrm{ET}_{0} / \mathrm{RC}$ significantly increases after $20 \mathrm{~min}$ but significantly decreases after $24 \mathrm{~h}$, and then gradually stabilizes to the control. TR $0 / A B S$ significantly decreases after $1 \mathrm{~h}$ for $\mathrm{EC}_{10}$ and increases after $24 \mathrm{~h}$ for $\mathrm{EC}_{20}$.

No significant difference is found in CAT activity, SOD activity, and GSH content at $\mathrm{EC}_{10}$; however, the POD activity is higher compared with the control (Figure 5). At $\mathrm{EC}_{20}$, the CAT activity, GSH content, $\mathrm{POD}$ activity, and SOD activity are significantly higher compared with those of the control, indicating that algae become stressed at $\mathrm{EC}_{20}$ of $\mathrm{La}\left(\mathrm{NO}_{3}\right)_{3} \cdot 6 \mathrm{H}_{2} \mathrm{O}$.

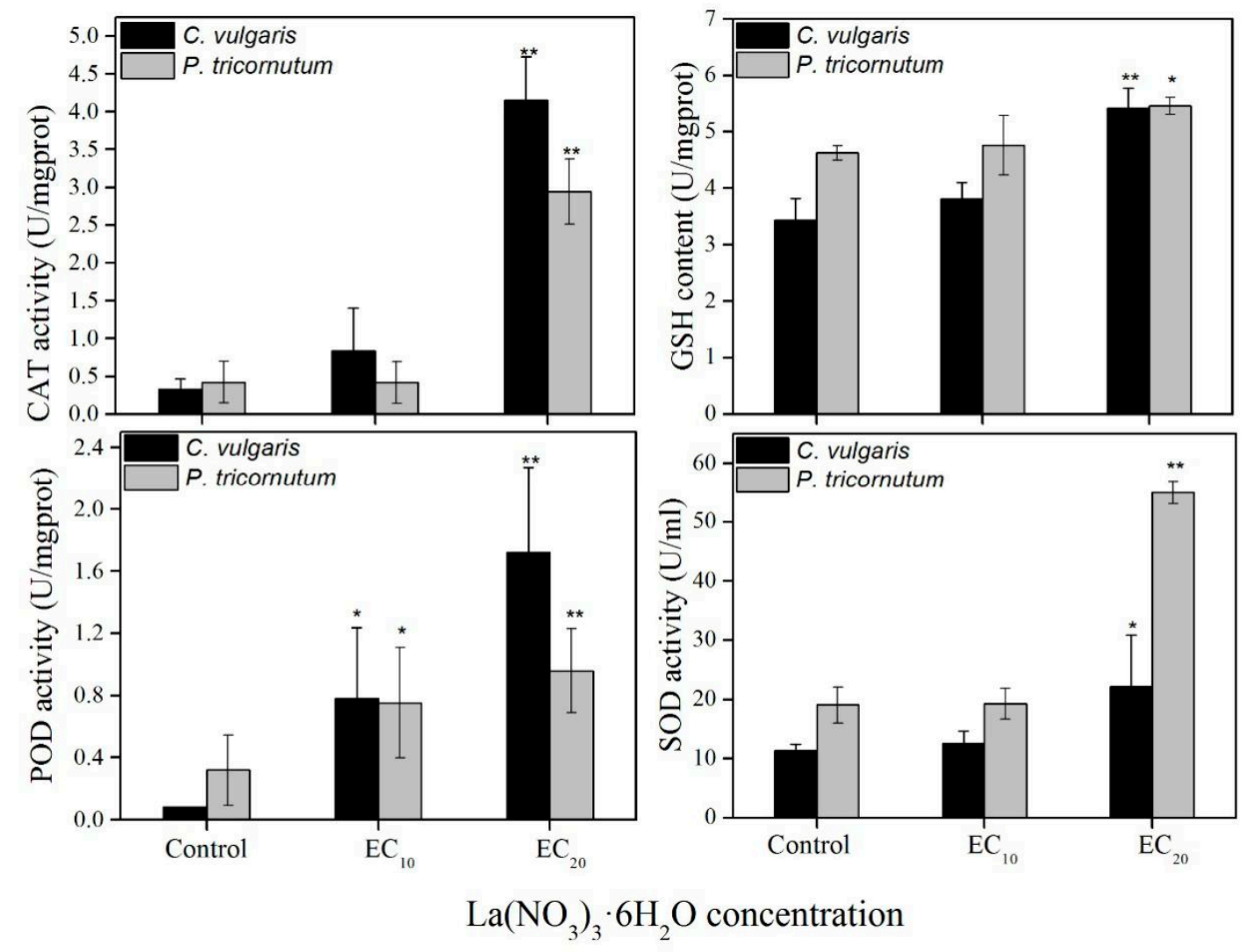

Figure 5. The effect of $\mathrm{La}\left(\mathrm{NO}_{3}\right)_{3} \cdot 6 \mathrm{H}_{2} \mathrm{O}$ on antioxidant enzyme (catalase (CAT), peroxidase (POD) and superoxide dismutase (SOD)) activities and glutathione (GSH) content of C. vulgaris and P. tricornutum after $96 \mathrm{~h}$. * Significant difference compared with the control $(p<0.05)$. ** Significant difference compared with the control $(p<0.01)$.

\section{Discussion}

In the present study, different concentrations of $\mathrm{La}\left(\mathrm{NO}_{3}\right)_{3} \cdot 6 \mathrm{H}_{2} \mathrm{O}$ show a significant inhibitory effect on the two algae. The inhibition rates increase with increasing concentrations of $\mathrm{La}\left(\mathrm{NO}_{3}\right)_{3} \cdot 6 \mathrm{H}_{2} \mathrm{O}$. Tai also shows that all single lanthanides have toxic effects on Skeletonema costatum [29]. Also, Goecke reports similar results that 72-h $\mathrm{EC}_{50}$ for four REE salts (Ce, Gd, La, and Pr) are between 1.2 and $1.4 \mathrm{mg} \cdot \mathrm{L}^{-1}$, and presumes that this inhibitory effect is caused by the nutrient sequestration from the algal growth medium [37]. 
However, Tai reports that the nitrates of REEs have no effects on algae at low concentrations (5-60 $\left.\mu \mathrm{mol} \cdot \mathrm{L}^{-1}\right)$ [29]. This finding is inconsistent with the present study in which $\mathrm{La}\left(\mathrm{NO}_{3}\right)_{3} \cdot 6 \mathrm{H}_{2} \mathrm{O}$ has an inhibitory effect on P. tricornutum, and the $\mathrm{EC}_{10}$ and $\mathrm{EC}_{20}$ are $1.262 \mathrm{mg} \cdot \mathrm{L}^{-1}\left(2.91 \mu \mathrm{mol} \cdot \mathrm{L}^{-1}\right)$ and $2.282 \mathrm{mg} \cdot \mathrm{L}^{-1}\left(5.27 \mu \mathrm{mol} \cdot \mathrm{L}^{-1}\right)$, respectively. The results indicate that low concentrations of nitrates of REEs also affect algae. Although the content of La is not high in the environmental water, it can accumulate to a damaging concentration, thereby potentially inhibiting the growth of algae.

When the growth of algae is inhibited by stress, it indicates that the photosynthetic system of algae has been damaged [20]. The OJIP curve values (O, OJ, JI, and IP) decrease with the increasing concentrations of $\mathrm{La}\left(\mathrm{NO}_{3}\right)_{3} \cdot 6 \mathrm{H}_{2} \mathrm{O}$ in the present study. The $\mathrm{O}$ point reduction indicates that the number of algae cells decreases. The decrease in JI and IP indicates that the high concentrations of $\mathrm{La}\left(\mathrm{NO}_{3}\right)_{3} \cdot 6 \mathrm{H}_{2} \mathrm{O}$ inhibit the photoactivation of PS II. This might be due to the increase in non- $\mathrm{Q}_{\mathrm{B}}$ in the PS II, blocking the transfer from $Q_{A}$ to $Q_{B}$ [38]. This is consistent with the finding that the photosynthetic system of algae is changed by polycyclic aromatic hydrocarbon stress [39]. However, the photosynthetic parameters are analyzed in the first $24 \mathrm{~h}$ in this study. $\mathrm{DI}_{0} / \mathrm{RC}$ decreases with the increasing concentration of $\mathrm{La}\left(\mathrm{NO}_{3}\right)_{3} \cdot 6 \mathrm{H}_{2} \mathrm{O}$, while $\mathrm{TR}_{0} / \mathrm{ABS}$ increases with the increasing concentration of $\mathrm{La}\left(\mathrm{NO}_{3}\right)_{3} \cdot 6 \mathrm{H}_{2} \mathrm{O}$. It showed that the trapping dose of PS II increases on $\mathrm{La}\left(\mathrm{NO}_{3}\right)_{3} \cdot 6 \mathrm{H}_{2} \mathrm{O}$ exposure, but the dissipated dose reduces. This result is inconsistent with the exposure of higher plants to aluminum (Al) [21]. This might be because REEs promote the growth of plants and algae.

To understand the changes in the fluorescence parameter values of PS II, the effects of low concentrations of $\mathrm{La}\left(\mathrm{NO}_{3}\right)_{3} \cdot 6 \mathrm{H}_{2} \mathrm{O}$ on the two algae are continuously monitored. The results show that, after $30 \mathrm{~min}, \mathrm{TR}_{0} / \mathrm{ABS}$ increases, and $\mathrm{ET}_{0} / \mathrm{RC}, \mathrm{ABS} / \mathrm{RC}$, and $\mathrm{DI}_{0} / \mathrm{RC}$ decrease on exposure to $\mathrm{La}\left(\mathrm{NO}_{3}\right)_{3} \cdot 6 \mathrm{H}_{2} \mathrm{O}$. This indicates that the trapping dose decreases, while the total excitation, dissipation dose, and electron transport rate increases on $\mathrm{La}\left(\mathrm{NO}_{3}\right)_{3} \cdot 6 \mathrm{H}_{2} \mathrm{O}$ exposure. It also reveals the decreased activity of electron transfer chains in photosynthetic systems after algae are stressed by contamination. This might be caused by the trapping and blocking of electron transfer of $Q_{A}$ [22] and also an inactivation of the PS II active center [40]. This result is consistent with the effect of low concentrations of nonylphenol on the Chlamydomonas reinhardtii strain CC125 and on Microcystis aeruginosa CPCC632 [41]. However, after $24 \mathrm{~h}$, the trapping values $\left(\mathrm{TR}_{0} / \mathrm{ABS}\right.$ ) reach a peak, and excessive absorption leads to the production of ROS, which causes peroxidation damage to the photosynthetic apparatus [42]. Therefore, after $96 \mathrm{~h}$, the antioxidant enzyme values at $\mathrm{EC}_{20}$ are significantly higher compared with the control, indicating that the antioxidant defense system was activated after the algae was stressed by $\mathrm{La}\left(\mathrm{NO}_{3}\right)_{3} \cdot 6 \mathrm{H}_{2} \mathrm{O}$. Other studies also show that the SOD activity and GSH content increase in the two algae to reduce the harm caused by active oxygen $[43,44]$.

\section{Conclusions}

In conclusion, $\mathrm{La}\left(\mathrm{NO}_{3}\right)_{3} \cdot 6 \mathrm{H}_{2} \mathrm{O}$ had a significant inhibitory effect on the two algae. In the first $48 \mathrm{~h}$, the inhibition by $\mathrm{La}\left(\mathrm{NO}_{3}\right)_{3} \cdot 6 \mathrm{H}_{2} \mathrm{O}$ is mainly caused by the destruction of PS II and the antioxidant system. After $48 \mathrm{~h}$, the PS II restores to the control levels. However, the oxidative stress remains on exposure to $\mathrm{La}\left(\mathrm{NO}_{3}\right)_{3} \cdot 6 \mathrm{H}_{2} \mathrm{O}$, and affects the growth of algae.

Author Contributions: Conceptualization, S.D. and D.S.; methodology, D.S.; software, Q.C.; validation, D.S. and S.D.; formal analysis, Q.C.; investigation, D.S.; resources, S.D.; data curation, D.S. and N.H.; writing-original draft preparation, D.S.; writing-review and editing, N.H. and S.D.; supervision, S.D.; project administration, D.S. and S.D.; funding acquisition, D.S., N.H. and S.D.

Funding: This study was supported by grants from the National Natural Science Foundation of China (No. 41476099 and No. 41676099), the China Postdoctoral Science Foundation (55350257), and the Science and Technology Project of Jiangxi Education Department (NO. GJJ170916).

Conflicts of Interest: The authors declare no conflict of interest. 


\section{References}

1. Yang, Z.; Woolley, A. Carbonatites in China: A review. J. Asian Earth Sci. 2006, 27, 559-575. [CrossRef]

2. Packey, D.J. Interesting Developments in the Rare Earth Market. Econ. Pap. A J. Appl. Econ. Policy 2013, 32, 454-461. [CrossRef]

3. Jin, X.; Chu, Z.; Yan, F.; Zeng, Q. Effects of lanthanum(III) and EDTA on the growth and competition of Microcystis aeruginosa and Scenedesmus quadricauda. Limnol. Ecol. Manag. Inland Waters 2009, 39, 86-93. [CrossRef]

4. Teng, Y.G.; Ni, S.J.; Wang, J.S.; Zuo, R.; Yang, J. A geochemical survey of trace elements in agricultural and non-agricultural topsoil in Dexing area, China. J. Geochem. Explor. 2010, 104, 118-127. [CrossRef]

5. Wang, L.; Zhong, B.; Liang, T.; Xing, B.; Zhu, Y. Atmospheric thorium pollution and inhalation exposure in the largest rare earth mining and smelting area in China. Sci. Total Environ. 2016, 572, 1-8. [CrossRef]

6. Wang, L.; Liang, T. Accumulation and fractionation of rare earth elements in atmospheric particulates around a mine tailing in Baotou, China. Atmos. Environ. 2014, 88, 23-29. [CrossRef]

7. Dai, S.; Xie, P.; Jia, S.; Ward, C.R.; Hower, J.C.; Yan, X.; French, D. Enrichment of U-Re-V-Cr-Se and rare earth elements in the Late Permian coals of the Moxinpo Coalfield, Chongqing, China: Genetic implications from geochemical and mineralogical data. Ore Geol. Rev. 2017, 80, 1-17. [CrossRef]

8. Li, J.X.; Sun, C.J.; Zheng, L.; Yin, X.F.; Chen, J.H.; Jiang, F.H. Geochemical characteristics of rare earth elements in the surface sediments from the Spratly Islands of China. Mar. Pollut. Bull. 2017, 114, 1103-1109. [CrossRef]

9. Yuan, J.F.; Mao, X.M.; Wang, Y.X.; Deng, Z.D.; Huang, L.H. Geochemistry of rare-earth elements in shallow groundwater, northeastern Guangdong Province, China. Acta Geochim. 2014, 33, 53-64. [CrossRef]

10. Zhuang, M.; Zhao, J.; Li, S.; Liu, D.; Wang, K.; Xiao, P.; Yu, L.; Jiang, Y.; Song, J.; Zhou, J.; et al. Concentrations and health risk assessment of rare earth elements in vegetables from mining area in Shandong, China. Chemosphere 2016, 168, 578. [CrossRef]

11. Yang, L.; Wang, X.; Nie, H.; Shao, L.; Wang, G.; Liu, Y. Residual levels of rare earth elements in freshwater and marine fish and their health risk assessment from Shandong, China. Mar. Pollut. Bull. 2016, 107, 393-397. [CrossRef] [PubMed]

12. Wang, B.; Yan, L.; Huo, W.; Lu, Q.; Cheng, Z.; Zhang, J.; Li, Z. Rare earth elements and hypertension risk among housewives: A pilot study in Shanxi Province, China. Environ. Pollut. 2016, 220, 837. [CrossRef] [PubMed]

13. Hao, Z.; Li, Y.; Li, H.; Wei, B.; Liao, X.; Liang, T.; Yu, J. Levels of rare earth elements, heavy metals and uranium in a population living in Baiyun Obo, Inner Mongolia, China: A pilot study. Chemosphere 2015, 128, 161-170. [CrossRef] [PubMed]

14. Xin, H.; Ding, Z.; Chen, Y.; Wang, X.; Dai, L. Bioaccumulation of lanthanum and cerium and their effects on the growth of wheat (Triticum aestivum L) seedlings. Chemosphere 2002, 48, 621-629.

15. Zeng, Q.; Zhu, J.G.; Cheng, H.L.; Xie, Z.B.; Chu, H.Y. Phytotoxicity of lanthanum in rice in haplic acrisols and cambisols. Ecotoxicol. Environ. Saf. 2006, 64, 226-233. [CrossRef] [PubMed]

16. Kobayashi, Y.; Ikka, T.; Kimura, K.; Yasuda, O.; Koyama, H. Characterisation of lanthanum toxicity for root growth of Arabidopsis thaliana from the aspect of natural genetic variation. Funct. Plant Biol. 2007, 34, 984-994. [CrossRef]

17. Wang, L.H.; Wang, W.; Zhou, Q.; Huang, X.H. Combined effects of lanthanum (III) chloride and acid rain on photosynthetic parameters in rice. Chemosphere 2014, 112, 355-361. [CrossRef] [PubMed]

18. Ippolito, M.P.; Fasciano, C.; d'Aquino, L.; Tommasi, F. Responses of antioxidant systems to lanthanum nitrate treatments in tomato plants during drought stress. Plant Biosyst. 2011, 145, 248-252. [CrossRef]

19. Perl-Treves, R.; Perl, A. Oxidative Stress: An Introduction. In Oxidative Stress in Plants; Inzé, D., Van Montagu, M., Eds.; Taylor \& Francis: London, UK, 2002; pp. 1-32.

20. Li, Q.; Lu, Y.; Shi, Y.; Wang, T.; Ni, K.; Xu, L.; Liu, S.; Wang, L.; Xiong, Q.; Giesy, J.P.; et al. Combined effects of cadmium and fluoranthene on germination, growth and photosynthesis of soybean seedlings. J. Environ. Sci. 2013, 25, 1936-1946. [CrossRef]

21. Jiang, H.X.; Chen, L.S.; Zheng, J.G.; Han, S.; Tang, N.; Smith, B.R. Aluminum-induced effects on Photosystem II photochemistry in Citrus leaves assessed by the chlorophyll a fluorescence transient. Tree Physiol. 2008, 28, 1863-1871. [CrossRef] 
22. Strasser, R.J.; Srivastava, A.; Tsimilli-Michael, M. The fluorescence transient as a tool to characterize and screen photosynthetic samples. In Probing Photosynthesis: Mechanism, Regulation \& Adaptation; Yunus, M., Pathre, U., Mohanty, P., Eds.; CRC Press: Boca Raton, FL, USA, 2000; pp. 445-483.

23. Dang, T.T.; Bowyer, M.C.; Van Altena, I.A.; Scarlett, C.J. Comparison of chemical profile and antioxidant properties of the brown algae. Int. J. Food Sci. Technol. 2018, 53, 174-181. [CrossRef]

24. Lei, A.; Hu, Z.; Wong, Y.; Tam, N.F. Antioxidant responses of microalgal species to pyrene. J. Appl. Phycol. 2006, 18, 67-78. [CrossRef]

25. Yu, B.; Zhao, C.Y.; Li, J.; Li, J.Y.; Peng, G. Morphological, physiological, and biochemical responses of Populus euphratica to soil flooding. Photosynthetica 2015, 53, 110-117. [CrossRef]

26. Aderemi, A.O.; Novais, S.C.; Mfl, L.; Alves, L.M.; Hunter, C.; Pahl, O. Oxidative stress responses and cellular energy allocation changes in microalgae following exposure to widely used human antibiotics. Aquat. Toxicol. 2018, 203, 130. [CrossRef] [PubMed]

27. Gao, Q.T.; Wong, Y.S.; Tam, N.F.Y. Antioxidant responses of different microalgal species to nonylphenol-induced oxidative stress. J. Appl. Phycol. 2017, 29, 1317-1329. [CrossRef]

28. Zhang, J.; Xie, Z.; Zhi, W. Oxidative stress responses and toxin accumulation in the freshwater snail Radix swinhoei (Gastropoda, Pulmonata) exposed to microcystin-LR. Environ. Sci. Pollut. Res. 2016, 23, 1353-1361. [CrossRef] [PubMed]

29. Tai, P.; Zhao, Q.; Su, D.; Li, P.; Stagnitti, F. Biological toxicity of lanthanide elements on algae. Chemosphere 2010, 80, 1031-1035. [CrossRef] [PubMed]

30. Kalaji, H.M.; Rackova, L.; Paganova, V.; Swoczyna, T.; Rusinowski, S.; Sitko, K. Can chlorophyll-a fluorescence parameters be used as bio-indicators to distinguish between drought and salinity stress in Tilia cordata Mill? Environ. Exp. Bot. 2018, 152, 149-157. [CrossRef]

31. Smith, P.K.; Krohn, R.I.; Hermanson, G.T.; Mallia, A.K.; Gartner, F.H.; Provenzano, M.D.; Fujimoto, E.K.; Goeke, N.M.; Olson, B.J.; Klenk, D.C. Measurement of protein using bicinchoninic acid. Anal. Biochem. 1985, 150, 76-85. [CrossRef]

32. Montavon, P.; Bortlik, K. Evolution of Robusta Green Coffee Redox Enzymatic Activities with Maturation. J. Agric. Food Chem. 2004, 52, 3590-3594. [CrossRef] [PubMed]

33. Peskin, A.V.; Winterbourn, C.C. A microtiter plate assay for superoxide dismutase using a water-soluble tetrazolium salt (WST-1). Clin. Chim. Acta 2000, 293, 157-166. [CrossRef]

34. Zhang, W.; Zhang, M.; Lin, K.F.; Sun, W.F.; Xiong, B.; Guo, M.J.; Cui, X.H.; Fu, R.B. Eco-toxicological effect of Carbamazepine on Scenedesmus obliquus and Chlorella pyrenoidosa. Environ. Toxicol. Pharmacol. 2012, 33, 344-352. [CrossRef] [PubMed]

35. Góth, L. A simple method for determination of serum catalase activity and revision of reference range. Clin. Chim. Acta 1991, 196, 143-151. [CrossRef]

36. Anderson, M.E. Determination of glutathione and glutathione disulfide in biological samples. Methods Enzymol. 1985, 113, 548-555. [PubMed]

37. Joonas, E.; Aruoja, V.; Olli, K.; Syvertsen-Wiig, G.; Vija, H.; Kahru, A. Potency of (doped) rare earth oxide particles and their constituent metals to inhibit algal growth and induce direct toxic effects. Sci. Total Environ. 2017, 593, 478-486. [CrossRef] [PubMed]

38. Singh-Tomar, R.; Jajoo, A. Alteration in PS II heterogeneity under the influence of polycyclic aromatic hydrocarbon (fluoranthene) in wheat leaves (Triticum aestivum). Plant Sci. 2013, 209, 58-63. [CrossRef] [PubMed]

39. Bascik-Remisiewicz, A.; Aksmann, A.; Zak, A.; Kowalska, M.; Tukaj, Z. Toxicity of Cadmium, Anthracene, and Their Mixture to Desmodesmus subspicatus Estimated by Algal Growth-Inhibition ISO Standard Test. Arch. Environ. Contam. Toxicol. 2011, 60, 610-617. [CrossRef] [PubMed]

40. Yamane, Y.; Kashino, Y.; Koike, H.; Satoh, K. Increases in the fluorescence Fo level and reversible inhibition of Photosystem II reaction center by high-temperature treatments in higher plants. Photosynth. Res. 1997, 52, 57-64. [CrossRef]

41. Perron, M.C.; Juneau, P. Effect of endocrine disrupters on photosystem II energy fluxes of green algae and cyanobacteria. Environ. Res. 2011, 111, 520-529. [CrossRef]

42. Song, Y.G.; Liu, B.; Wang, L.F.; Li, M.H.; Liu, Y. Damage to the oxygen-evolving complex by superoxide anion, hydrogen peroxide, and hydroxyl radical in photoinhibition of photosystem II. Photosynth. Res. 2006, 90, 67-78. [CrossRef] 
43. Zhuang, L.E.; Zhao, L.; Yin, P.H. Combined algicidal effect of urocanic acid, N-acetylhistamine and l-histidine to harmful alga Phaeocystis globosa. RSC Adv. 2018, 8, 12760-12766. [CrossRef]

44. Tan, S.; Hu, X.L.; Yin, P.H.; Zhao, L. Photosynthetic inhibition and oxidative stress to the toxic Phaeocystis globosa caused by a diketopiperazine isolated from products of algicidal bacterium metabolism. J. Microbiol. 2016, 54, 364-375. [CrossRef] [PubMed]

(C) 2019 by the authors. Licensee MDPI, Basel, Switzerland. This article is an open access article distributed under the terms and conditions of the Creative Commons Attribution (CC BY) license (http://creativecommons.org/licenses/by/4.0/). 